\title{
Perception of Food and Nutrition and Dietary Recommendation in Health and Disease: Focus on Caraka-Suśruta Saṃhitās
}

\author{
Sukta Das* \\ (Received 25 November 2014; revised 8 January 2015)
}

\begin{abstract}
The earliest among the classical medical texts of India are Caraka Saṃitāa and Suśruta Saṃhitā, and of the two Caraka's compendium, essentially on medicine, is believed to be earlier. Suśruta Samhitā, the other medical treatise is more systematic, concise and precise and is the oldest known work to deal predominantly on surgical practices. The significance of these two ancient treatises lies in their detailed message on promotion of human health and treatment of diseases based on rational concepts. The objective of Caraka Saṃitā is to enumerate medical practices for achieving dhātusāmya or equilibrium of sustaining and nourishing factors of the body, so that man can enjoy a happy long life devoid of ailments. Suśruta Samhita , although dealing with Śalyatantra or surgery, also projects the basic philosophy of preservation of health and longevity. The historical dating of the works as well as the identities of both Caraka and Suśruta have been extensively debated, but there is no doubt regarding their importance with respect to the content which exposes the state of understanding of health, diseases and their treatment in early India. $\bar{A} h \bar{a}$ ratattava or diet and nutrition is an integral part of Caraka Samhitā and Annapānavidhi or proper intake of food has been emphasized in Suśruta Samhitā for good health. Knowledge on the concept of a balanced diet is also well expressed in the two Saṃitās where mention is made of Sarvagraha meaning total quantity of food and Parigraha denoting quality of individual items essential for a "wholesome" diet from the nutritional viewpoint and adverse influence of "unwholesome" food items in the context of health and disease. It appears that a detailed search on this important aspect of medicine (health and nutrition) documented in the two antique medical texts did not receive their due attention so far. The present narration therefore is to highlight the significant features of dietary principles related in the outstanding medical texts which reflect an understanding of food, diet and nutrition for preservation and protection of normal health and their association and role in aetiology and management of diseases in early Indian medical practice.
\end{abstract}

Key words: Āhāratattāva, Annapānavidhi, Caraka Saṃitā, Diet, Food, Nutrition, Suśruta Saṃhitā.

\section{Introduction}

The essentiality of food for sustenance of life is known from prehistoric times. Food being recognized as important for life, primitive man had been in search for eatables and adapted progressively through centuries to a wide range of naturally occurring foods. Early man procured food by hunting and gathering. With the advent of agriculture and with development of the ability to produce and store food, profound changes were noted in the food habit as some food items could be preferentially cultivated and procured. Radical changes in methods of food production, processing, storage and distribution since the industrial revolution brought about major changes in the nutritional components of human diet. The health benefit of the increased and assured food supply was reflected in elimination of starvation and many deficiency diseases. Improvement in nutritional status led to increase in childhood

\footnotetext{
*Cancer Foundation of India, Kolkata; E-mail: suk_tadas@yahoo.com
} 
growth rate, resistance to infectious diseases and increase in life expectancy. However many diseases emerged as a long term effect of "affluent diet" characterized by an excess of energy-dense fats and sugars, which became so apparent as to draw specific attention to "healthy food". The dynamic association between changes in a population's diet and its health is well reflected in the disease and mortality profiles of a population. Health of a population is found to largely depend on specific components of the diet which can increase or decrease the probability of disease risk and mortality.

Food consists of any solid or liquid substance, of plant or animal origin, which is consumed to sustain life by providing nutritional support to the body. The substance ingested is assimilated in the body cells to produce energy, maintain life and stimulate growth. The essential nutrients of food are comprised of carbohydrates, fats, proteins, vitamins and minerals. The sum total of foods or mixture of foods consumed daily by an individual is referred to as diet. The term diet also implies use of intake of specific food items to provide nutrition according to body's need in different ages and conditions for example for maintaining good health, management of weight and diseases and to prevent or recover from diseases. Dietary habits may vary according to individual choice or culture. Generally humans are omnivores but each culture and each person holds some food preferences or some food taboos due to personal tastes or ethical reasons. It can define cultures and can often be related to religion. Traditionally followed dietary choices are usually more or less healthy and play a significant role in the quality of life, health and longevity. Nutrition is actually the science of food and its relationship to body growth and development and maintenance of health. Dietetics is the practice of the principles of nutrition. Human nutrition is complex as there is the freedom to select from unlimited and accessible range of foods, although the major constraints in selection are cultural and economic factors. In the modern global campaign on health for all, promotion of proper nutrition has been highlighted and nutritional indicators have been developed to monitor the health status.

Food has been classified in many ways in different periods of history viz. by origin, chemical composition, nutritive value, predominant function etc. The importance of the relationship between proper food and good health has however been realized at all times. The association of some dietary factors and particular diseases were also not unknown in the early days. Existence of man has in fact been largely controlled by its struggle in search of food through centuries. The science of nutrition however had a limited range until the $19^{\text {th }}$ century. Yet it is amazing to know the level of understanding on the role of food for growth, reproduction, maintenance and repair of the body since ancient times in India. Consideration of food in relation to health is reflected in some Vedic mantras and philosophical discourses of Upanisads. The Rgveda has attributed divinity to anna (food) as God Pitu. The word pitu frequently mentioned in Rgveda has been explained as pālakamannam implying nourishment. Indian medical texts have dealt in great detail and depth the classification of food with respect to origin, function and nutritive value. Specific recommendations were made keeping in view the age, climatic and seasonal factors, state of health of a person, all of which suggest a profound knowledge on the principles of nutrition. According to early Indian medical practices the food we consume and the manner in which it is taken is in harmony with our nature which has strong bearing on health and emergence of disease. Practice of medicine in the system has therefore incorporated dietary therapy as one of its essential component since early times.

Knowledge on the concept of a balanced diet is well expressed in Caraka Samhitā where mention is made of Sarvagraha meaning total 
quantity of food and Parigraha denoting quality of individual items essential from the nutritional viewpoint. Mention has been made of "wholesome" and "unwholesome" food items in the context of health and disease. Suśruta Samhitā underlined "prudent food" as the foundation of strength and vitality. Āharatattva or diet and nutrition is an integral part of Caraka Samhitā and Annapānavidhi or proper intake of food has been emphasized in Suśruta Saṃitā for good health.

The present study is an exploration of the understanding on food, diet and nutrition, referred to in these two outstanding texts on medical and surgical practices of ancient India, with respect to normal health as well as their association with the aetiology of diseases and in their management.

\section{Importance of Caraka Samhitā and Suśruta Saṃhitā}

Caraka and Suśruta Saṃhitā are the earliest among the classical medical texts of India. The treatises are significant because of their rational basis to the concepts and discourse. Of the two, Caraka's compendium, essentially on medicine, is believed to be earlier. The objective of Caraka Samhitā is to enumerate medical practices for achieving dhātusāmya or equilibrium of sustaining and nourishing factors of the body, so that man can enjoy a happy long life devoid of ailments. As stated in the scientific synopsis published by the Indian National Science Academy, Caraka Samhitā was actually a redaction by Caraka of the original work of Ätreya Punarvasu who was a teacher in Taxila University during the age of Buddha (Ray and Gupta,1965, p.26) There are several legends centred round the name of Atreya, the venerable medical authority. Evidence of a historical Ātreya has been put forward by the existence of a manuscript entitled Ätreya Saṃhitā in the British catalogue number 2640, consisting of 164 folios (Naqvi, 2011, p.56). Unfortunately no translation or editorial work has ever been carried out on this document. Therefore we are in the dark about the date, circumstances leading to its discovery and even its authenticity. It is assumed that based on the teachings of Âtreya, the physician who formulated the basic concepts in medicine representing the School of Ātreya, his disciple Agniveśa composed the Agniveśa Tantra. This was further refined and enlarged as Caraka Saṃitā and redacted by Drụhabala - a scholar from Kashmir in around $6^{\text {th }} / 9^{\text {th }}$ century AD. No definite dating of the physicians and compositions has been universally accepted. Some scholars, based on Chinese sources, identify Caraka as a physician in the court of Kaniska who ruled in the second century AD. Internal evidence indicates that this Samhitā is a compilation and Caraka was probably an intermediate editor and reconstructor of the work.

Suśruta Samhitā, the other medical treatise is predominantly a surgical text representing the Indian School of Śalyatantra, which also projects the basic philosophy of Āyurveda for preservation of health and longevity. This text is more systematic, concise and precise than Caraka Samhita and is the oldest known work to deal exclusively on surgical practices. Suśruta is regarded as the Father of Anatomy and Surgery and the first to describe the method of dissection of human cadavers. The chronology Committee of the National Institute of Science of India (1952) opined that third -fourth centuries AD may be accepted as the date of recension of Suśruta Saṃhitā by Nāgārjuna which formed the basis of Dallana's commentary. Bower Manuscripts discovered in 1890 at Kashgarh in Chinese Turkistan make mention of Suśruta's name along with Ātreya, Jivaka and other old Masters (Saha, 1985, p.7). Paleographically these manuscripts belong to the fourth to sixth century AD (Chattopadhyay, 1977, p. 38). Hence it is assumed that the Suśruta Samhitā was probably compiled prior or within this time-frame. The original Suśruta Samhitā is considered to be a representation of a series of discourses by the holy 
sage Dhanvantari -the so called creator of the science of surgery to his disciples (Ray, Gupta and Roy, 1980, p.32).

Although the dating of the works as well as the identities of both Caraka and Suśruta have been debated by scholars, there is no doubt regarding the importance of these ancient medical texts with respect to their content which exposes the state of understanding of health, diseases and their treatment in early India.

\section{Definition of Health and Disease in Caraka-Suśruta Sạ̣hitās}

Caraka Saṃitā defines health as a condition which is the best source of virtue, wealth, gratification and emancipation while diseases are destroyers of this source of welfare and life itself (CS.Sū.1.15-17). According to Suśruta Samhitāa a healthy person is one in whom there is perfect balance of all body functions in equilibrium with the mind and soul, any deviation from which results in diseases (SS.Sū.15,41). These definitions are so comprehensive incorporating the physical, psychological, social and spiritual aspects of human life that it can in no way be underrated in comparison to the modern definition of health as "a state of complete physical, mental and social well-being and not merely absence of disease and infirmity" provided by WHO based on the conference held in New York in 1946 (WHO 1946). This statement was further amplified in 1978 to include the "ability to lead a socially and economically productive life” (WHO, 1978; Ustin, and Jacob, 2005).

\section{Basic Principles of Āyurveda}

In order to understand and appreciate the recommendations made with respect to food, diet and nutrition in health and disease, it would be appropriate to consider the basic principles of Āyurveda or the "science of life"(Dash 1978; Frawley1997, pp.13-45). The history of medical knowledge in India dates back to Vedas and Ayurveda is believed to be a branch (upaveda or upāniga) of Atharvaveda which deals with the healing art. While modern medicine interprets disease in terms of pathophysiology of the body, Ayurveda considered all diseases to be a result of an imbalance or derangement of the three doșas or biological humors - the primary life forces in the body viz. vāta, pitta and kapha which correspond to the elements of air, fire and water. As active or mobile elements they control the life process of growth and decay. The three dosas account for all the psycho-biological functions of living being. They are the functional elements of the body which remain in an unstable and vulnerable state. In healthy condition they remain in a balanced state. The most unstable of the three dosas is vayuu and kapha is the most stable one. All doșas have specific properties in the body. The physical and physiological attributes of $v \bar{a} y u$ comprise of mobility, breathing, natural urges, all motor and sensory functions, secretions and excretions and its psychological attributes are restlessness, anxiety and fear. Pitta contribute to physiological generation of heat, hunger, thirst, digestion, metabolism and vision and is associated with intelligence, anger, hate and malice. Body building, stability and immunity are controlled by kapha and attribute to patience, forgiveness and attachment. In brief, vāta control all neurological function/activities, pitta control digestion and metabolism and kapha attributes to anabolic activities and body building.

Doșas act on the dhātus or body constituents which comprise of rasa-the primary essence derived from food (body fluid), which produce rakta (blood), māmsa (muscle), meda (fat), asthi (bone), majja a (marrow) and sukra (egg and sperm), to determine the state of health or disease in the body. Thus when out of balance, the dosas are the causative factors in the disease process. The essence of health is thus a balance of dhātus and doșas i.e. dhātusāmya. 
The three dosas are considered to be in a state of equilibrium in normal condition of health. Disease manifest when they are provoked (CS.Vi.6,13). The healthy functioning of the biological process depends on the presence of a normal state of humors, while malfunctioning arise out of their abnormal or deranged state, resulting in various diseases. The concept that wholesome food helps in maintaining the normal balance of dosas and consequently good health and longevity whereas unwholesome food causes derangement of the same leading to diseases, has been expressed throughout Caraka and Suśruta Saminitās.

\section{Food, Diet, Metabolism and Nutrition}

Development of nutritional science in modern medicine, which is fairly recent, has established a definite and strong influence of food and nutrients on the state of health at all stages of life. Nutritional care is considered to be one of the most vital requisites for sustenance of life as it is associated with metabolic processes related to growth, maintenance, repair and other physiological functions in healthful conditions in a lifetime as well as in diseased conditions. Interestingly, there is a long tradition of correlating food and health in India and most of the socioreligious practices had a strong association with food. Prayers for nutritional food for physical valour are to be found in many Vedic hymns (Rgveda 5.44.10; 6.1.5). Kautilya’s Arthaśāstra has indicated that a good meal should consist of one prastha (about 500 grams) of pure unbroken rice, one fourth of this quantity of pulses, one sixth of a prastha of ghee or oil and one sixty fourth of a prastha of salt (Om Prakash, 1961, pp. 87-101) which compares well with the basic and main items of a balanced diet prescribed by modern nutritionists which is essentially composed of carbohydrates, proteins, fats/oils and salts. The Sanskrit terms like āhāratattva, poṣana, paurṣi and pālana all refer to nutrition and nourishment (Achaya, 1998, p.171).
It is striking as well as amazing to find a deep understanding of food and nutrition embodied in Caraka Samhitā and Suśruta Samhitā, which considered the importance of proper eating habits for providing not only nourishment for growth, development and procreation but also the essentiality of the right food for a lifelong positive health. Food was considered as the vital breath of living beings and the body as the product of food and drinks consumed (CS. Sū. 27.3-4). Food is also responsible for producing diseases (CS.Sü.28.5). It was also known that body needs to be nurtured from birth or even earlier (prenatal state). Food was perceived as that which nourishes dhātus (building blocks of the body) and ojas (vital energy) to provide strength and immunity for all aspects of the life process and that promotion of life and health is dependent on agni, the digestive fire or product of food metabolism (CS.Ci.15, 35). According to Suśruta Saṃhitā (SS.Sū.46,3) while diet ( $\bar{a} h \bar{a} r$ ) is the essential factor for origin and maintenance of life which provides strength, immunity and sustenance of life function, it is also the causative factor for disease. Therefore all living beings were perceived to be influenced by and dependent on their diet. These early perceptions suggest a comprehensive understanding of food and metabolism and their role in nourishment for building, maintaining and promoting a healthy body and mind, all of which are issues that have been scientifically explored with the emergence of nutritional science as a specialized branch of modern medicine (Crayhon, 1997, p.15; Mennell, Murcolt and Van Otterloo, 1993, p.36). In fact ahāratattva or the knowledge of diet and nutrition forms an integral part of Caraka Saṃhitā, which has been dealt with in great detail in many of the chapters of Sütrasthāna, where the importance of proper dietary habit for good health is highlighted. Wholesome food (hita) is promoter of health and prevents diseases while unwholesome food (ahita) is held responsible for most of the human ailments (CS.Sū.25,31). 
Likewise, annapāna vidhi or the code of proper dietary practice has been stressed upon throughout Suśruta Samhita. While highlighting the importance of wholesome food combination (samāsana), avoidance of irregular eating, like food taken in excess, in small quantity or untimely (visamāsana), as well as eating during indigestion (adhyāsana), is mentioned (SS.Sū.46: 508-509). The influence of food and drinks in health and disease and the importance of selecting a variety of food items in the daily diet under different physiological, pathological and seasonal conditions have been explicitly discussed throughout this chapter (SS.Sū. 46). Caraka's emphasis on virudhāhāra i.e. dietary incompatibility is to be taken note of. It has been mentioned that eighteen external and internal factors like quantity, composition, place, time, season, agni, doșa, health conditions, processing of food, eating rules etc determine whether food is wholesome for a person or not. These factors have been clearly explained and exemplified in the text. (CS.Sū. 26, 86-101)

Modern dietetics has provided strong evidences for the importance of food selection with respect to these factors known to the early Indian physicians. A comprehensive concept of food metabolism found in the two medical texts also merits appreciation. Food being properly consumed and digested were to be metabolised to produce agni (vital energy), rasas (clear essence of food) and malas (waste products like sweat, urine, faecal matters). The āhāra rasa (nutrients from food) thus produced nourish the dhātus to maintain the normal body growth and functions while the malas are excreted (CS.Su. 28,4); the body is thus a product of food eaten, drunk, licked and devoured, the wholesome and unwholesome determining health and disease in conjunction with other factors (CS.Sū.28,5). Production of agni or body heat (metabolic energy) was thought to be the basis of life process (metabolism) (CS.Vi. 6.12). Any abnormality in the body heat results in diseases and in case of suppression or absence of the same there is an end to life (CS.Ci.15.3-4). Food and its digestion was known to be the source of body heat and food ingested was considered to undergo digestion in two phases, prapāka in the mouth and vipāka in the gastro intestine before it is absorbed in the large intestine (CS.Ci.15.5, 911).

It is interesting to note that rasa is perceived as the pure (sara) and most minute (paramasuksma) essence of well digested food which circulates in the body through ten ascending, ten descending and four oblique sir $\bar{a} s$ (blood vessels) originating in the heart to sustain and maintain the normal functions of the body (SS.S $\bar{u} .14,3)$ and that digestion involves upayuktasya (ingestion) i.e. proper intake of food according to the rules prescribed under the code of healthy conduct. Different types of ajīrna (indigestion) have been described which is caused by not following the rules of proper food intake (SS.Sü.46,499).

In connection with food an important feature of Caraka-Suśruta Samhitās is the elaborate listing and categorization of food items. Caraka's concept on dvādaśa āhāra varga reflects a sound knowledge base with respect to diversity of food and their source. This is so exhaustive that there seems to be no space for further addition even today. In Caraka Samhitā food items are classified with respect to their source and grouped as heavy, light, cold and hot and the list includes cereals, legumes, leafy green and other vegetables, fruits, meat of a wide variety of animals, fish, milk, honey, sugar, edible oil, salt and multifarious drinks (CS.Sü.27). The taste, digestibility, metabolic and physiological action and medical efficacy of food items have been described elaborately in Suśruta Samhitā (SS.Sū.45; SS.Sū.46). Food is regarded as soft, liquid, lickable and hard which according to the composition and ways of processing exert different effects in the body; therefore without knowing the basic nature 
of food, the physician is not to prescribe them (SS.Sü.46.3). Fruits (phala varga) are grouped as āmla (sour), madhura (sweet) and tikta-kașāya (bitter pungent) and their variants along with their biological properties (SS.Sü.46, 139-210). Milk has been considered as a complete food for body and brain (CS.Sü.1.105-113; SS.Sū.45.44-68) and $\bar{a}$ mlaka as best among fruits (SS.Sü. 46,143-144). Mention is to be found of many food preparations like mandas (thick creamy preparation), yusas (soup) and gruels and sweet dishes, prepared by combination of a variety of rice, legumes, vegetable, meat, ghee and milk, which are flavoured with spices, sweetened or scented, as well as juices and alcoholic drinks.

Since the essence of food and drinks saturates all the physiological elements, one should protect rasa with proper food, drink and behaviour (SS.Sū.14.11-12). Āhāra rasa normally nourishes all dhâtus, but is deficient in the old due to geriatric decay in the body (SS.Sü.14.19). Dhātus remain in a balanced state in those who take moderate diet regularly, due to which the body attain a good physique, capable of all activities, is strong and tolerant to difficult physiological and seasonal situations (SS.Sū.15.34). Both obese and lean persons are incapable of attaining this state and hence susceptible to diseases (SS.Sü.15, 3536). Those who have no self restraint and eat voraciously without considering the quantity, gets indigestion, the root cause of many diseases(SS.Ci.39.37). These observations are strong indicators of the existence of a scientific perception and cardinal concept on human dietetics in early Indian medical thought.

\section{Recommendations on Food and Diet FOR A HEALTHY LifE}

The emphasis on food as promoter and protector of health is to be noted from the first chapter of the first section (Sütrasthānam) of Caraka Samhitā. Here it is stated that the best source of virtue, wealth, gratification and emancipation is a disease free condition and that diseases destroy all these sources of welfare and life itself (CS.Sū.1.15-17). A state of dhātusāmya (healthy state) can be achieved by use of pacifiers of the dosas which can be obtained from different food sourced from animals, plants and earth (CS. $S \bar{u} .1,67-73)$. Reference to all the three sources of food suggest the knowledge that the essential food components which are needed to provide complete nourishment for the body (the macronutrients protein, carbohydrate, fat and the micronutrients - essential vitamins, phytochemicals and trace elements) are not available from a single source. Interestingly specific mention is made of earth being the source of gold and lohas viz. silver, copper, iron, tin, silica, calcites and salts (CS.Sü.1,68-73). It is to be noted that one who desires happiness were advocated to make the best effort to practice the "wholesome" in respect to diet, conduct and action(CS.Sü.7,60) which can be compared to what we now refer to as "healthy lifestyle" in relation to prevention of chronic diseases like diabetes, heart diseases, and cancer (WHO 2003).

Wholesome food are those which maintain the balanced state in normal condition and is able to restore equilibrium in mal-balanced ones, while others that do not have these qualities are unwholesome (CS.Sü.25,33). Therefore only the wholesome food was considered to promote growth and development and consumption of the unwholesome is the root cause of all disorders (CS.Sū.25.31). It has been stated that no substance is absolutely wholesome or unwholesome, but can be so by nature (svābhāvatah) and combination (samyoga) of substances (SS.Sū.20.3). Absolutely wholesome items in general are water, ghee, milk, rice, pulses, barley, wheat, āmalaka, rock salt etc. which can be prescribed in diet of all persons (SS.Sū.20,4-5). Combination of cucurbitous fruits, mushrooms, bamboo shoot, horse gram, sour fruits, meat, wine etc should not be mixed with milk as that becomes absolutely unwholesome (SS.Sū.20.8). Whatever food that aggravates dosa 
and does not expel or vitiate rasa is unwholesome (SS.Sū.20.20)

Diet may consist of preparations which can be eatable, chewable, drinkable and lickable, and according to the property of food items innumerable variations can be made. They have been defined from different aspects in the Samhitās and are grouped as hot, cold, heavy, light, unctuous, rough, dull, sharp, stable, mobile, soft, hard, non-slimy, slimy, smooth, course, minute, gross, viscous and liquid. According to their effect on the body they are to be considered as wholesome or unwholesome (CS.Sū.25.36). Some of the wholesome items mentioned are śăli rice, green gram, rain water, rock salt, jivanti (Dendrobium macrei Linn. or cork (swallow wort), antelope or quail meat, rohita fish, cow's milk and ghee, sesamum oil, fish fat, ginger, grapes, cane sugar and a diet composed from these substances are naturally wholesome (CS. Sū.25.38). Yavaka (barley), black gram, river water- particularly in rainy season, beef and frog meat, sheep milk and ghee, potato etc are among the unwholesome items (CS.Sū.25.39). Attention has been drawn on aștavidha āhāra or eight principles of diet which are to be taken into consideration in planning of a wholesome diet viz. nature, processing, combination, quantity of food items, time, place and rules of food intake as well as the personal nature of the consumer (CS.Vi. 1,21). An important and specific recommendation on āhāravidhi is to eat after considering his own self (CS.Vi.1,25). One who lives following the dietary rules never suffer from severe disorders. According to Suśruta Samhita the twelve factors that need to be considered in relation to food consumption are whether it is cold, hot, unctuous, rough, liquid, dry, deficient in quantity, doșa pacifier, maintains body and to be taken once or twice daily and is to be taken mixed with drug(SS.Utt.64,36). The rationality of this dietary practice cannot be overlooked and appreciated despite the fact that in the present frame of time and situation some of the factors many not seem relevant.
Importance of anupāna or drinks to be taken in association with food was also reiterated. Food being motionless and un-moistened produces distress if suitable liquid drink is not taken with food (SS.Sü.46.439). Hot water is the best drink in vāta and kapha and cold water in rakta pitta. Anupāna quenches thirst, stimulates digestion, pacifies dosas, removes fatigue and exhaustion (SS.Sū. 46, 434-437).

Among the beneficial food items repeated mentioned of śāli rice is to be found. It is sweet, light and easily digested, promote strength, pacifies pitta but slightly increases vāta and kapha; lohitaka (red) is adjudged as the best variety of śăli rice because it is tridoṣa alleviating, diuretic, wholesome for eyes and voice, promoter of complexion, pacifier of thirst and eliminates all diseases (SS.Sū.46,4-6). Mugda and masūrika are recommended for being superior among pulses (SS.Sū.46,29-30) and Bengal gram pacifies kapha and rakta pitta and is an excellent pacifier of $v \bar{c} t a$ when mixed with ghee (ghrta) (SS.Sü.46.31-32). Godhūma (wheat) is heavy, unctuous, excessively cold, laxative, promote strength and semen, pacifies vāta and pitta and increases kapha (SS.Sū.46.43). Yava (barley), though included under unwholesome in Caraka Samhitā, is considered wholesome due to being sweet and astringent with pitta and kapha pacifying properties (SS.Sü.46.41-42). Meat of black and white deer are beneficial because of their role in stimulation of digestion and strength promotion; they are also light and pacifier of all three doșas (SS.Sü.46.55-56). Both the texts have provided exhaustive lists of a wide range of food items to choose from during formulation of balanced wholesome diets.

The different requirement of nourishing food with respect to seasonal variation also did not escape attention. For this purpose the year was grouped as adana comprising of sisira, vasanta and grșma (winter, spring and summer) and visarga to include varșă, sarad and hemanta 
(monsoon, autumn and early winter, CS.Sū.6.4) when the weather conditions demanded specific dietary selection and accordingly recommendation were made (CS.Sū.6,6-7; SS.Utt.64.5). Like, in rainy season to avoid sluggishness in digestion and aggravated $v \bar{a} y u$, the prescribed diet was to contain astringent, bitter and pungent items; those food that are warm and appetizing, neither too fatty nor rough, were beneficial along with cooled boiled water preferably mixed with honey (SS.Utt.64,6-8). Suggestion for autumn (SS.Utt.64.13-14) was to carefully choose astringent, sweet and bitter items like milk, sugarcane, honey, śâli rice, green gram, meat of wild animals etc. Wholesome for winter consists of salty, alkaline, bitter, sour and pungent items, warm food with ghee and oil (SS.Utt.64.18-19). In springtime food items which are irritant, rough, alkaline, pungent and astringent eg. barley, green gram, honey etc. are useful (SS.Utt.64,23-24). Drinks beneficial in summer are sweet mantha (lassi) and fragrant cold drinks mixed with sugar and food are to be sweet, light and cold (SS.Utt.64.29-30). Following this code of food consumption for different seasons one is spared of many seasonal disorders (SS.Utt.64.35). This idea definitely has a scientific basis and may be considered still relevant. We all know thoughtful selection of food items do help in protecting from many seasonal health problems.

The nutritive fluid derived from food was known to pervade the body through channels and to be responsible for formation of blood, flesh, fat, bone marrow, semen, ligaments and clear fluid (plasma/serum) as well as the sensory faculties (CS.Sū.28,3-5).

It was observed that nutrition, which is required for physical and mental growth and development, had to be provided from the foetal stage. The embryo after formation in the uterus grows with the utilization of suitable nourishment and in condition of malnutrition conception of embryo is not possible (CS.Sā.3.12). Nutritional substances were delivered from the mother to the growing embryo through the umbilical cord (CS.Śă.6.21; SS.Śā.3.31). Therefore the pregnant women were advised to take relishing and nutritious food and drinks and refrain from eating dry, stale, rotten and decomposed food (SS.Śā.10.3). In the context of origin of embryo, mention is made of food components comprising of six rasas (nourishment) from which embryo develops (CS.Śā.2.4). The six rasas are madhura (sweet), amla (sour), lavaṇa (saline), kațu (pungent), tikta (bitter) and kașāya (astringent) (CS.Sū.26.9) which when used in proper quantity are beneficial, otherwise they become harmful (CS.Sü.26.40-44), necessitating their presence in the right quantity according to the physiological requirement. Importance of wholesome diet for easy delivery of fully formed normal foetus (CS.Śă.2.6) and lack of proper nutrition as a factor for foetal abnormality (CS.Śă.2.29-30) also did not remain undermined/ unnoticed. Maintenance of the foetus was known to be accomplished by wholesome substances from the pregnant women since the foetus gets connected to the mother through vessels (CS.Ś $\bar{a} .4 .15)$. Items which were hot, heavy, irritant and intoxicating, received from the mother, were considered likely to affect the foetus and were therefore to be avoided by the pregnant woman (CS.Śā.14.18). To ensure dietary management of proper nutrition for both mother and child and for a complication free easy delivery specific recommendation was made (SS.Śă.10.4). It was suggested that the pregnant woman consume mainly sweet, cold liquids in the first three months of pregnancy, followed by boiled sastika rice with milk in the third month. Food mixed with milk and butter and relishing preparations of meat was also to be given from the fourth month along with adequate quantity of fluid. During fourth to six months, rice with curd, milk and ghee were considered beneficial. Liquid gruels of rice, vegetables, meat and ghee provided proper nourishment. It was also suggested that addition of substances be made to the diet which 
would help in elimination of wind and faeces by proper bowel movement. Realizing the importance of nourishment for the growing foetus, the mother and for lactation (CS.Śă.6.21,23), a good dietary regimen is therefore recommended for the pregnant woman(CS.Śä.8.32,48-49) where digestibility and nourishment seems to be the main concern. It is also stated that the foetus dries up in a state of malnutrition of the mother (CS.Śä.8.26). The rationality and scientific basis of this diet planning conceived in the early times cannot be overlooked in the current context.

The post-delivery diet, both for mother and child, also received equal attention. The diet suggested for the mother to enhance strength and digestive power comprised of fatty gruel or milk gruel for three days followed by cooked sali rice and meat juice processed with barley, jujube (Indian plum) and horse gram (SS.Śā.10.16). Feeding a diet consisting of barley, wheat, śali or svāstika rice, meat juice, wine, sour gruel, oil cake, garlic, fish and vegetables was recommended for proper lactation (SS.Śă.10.30). This undoubtedly reflects the knowledge on the relation between diet and milk production, the benefit of breast feeding as well as the role of mother's milk in physical development and health promotion of the child.

During birth ceremony immediately after the delivery, the new born was given to lick gold powder mixed with honey and ghee (SS.Śā.10.13). The significance of this ritual needs to be explored in connection with nourishment of the baby. Could it be a way of providing micronutrients to the child from external sources other than mother's milk? It appears that supplementation of milk or solid food of the child with herbs and fruits in later stages for ensuring health, strength, intellect and life span (SS. Śă. 10.45) was evidently to provide vitamins and micronutrients and roughage (fibres). In the absence of breast milk, intake of goat or cow milk (SS.Ś̄a.10.48) and solid but light food was to be started from the sixth month (SS.Śā.10.49). These recommendations in Caraka-
Suśruta Samhitās still hold true and is in agreement with the requirement in developing process.

Culinary skill and eating practices are both science and art of healthy living and progress in these aspects may be used as an index of evolution of civilized society. Considering this parameter, both Caraka and Suśruta Saṃitās reflect the existence of a highly cultured culinary practice in early India. Various food preparations are described and the palatability of food preparations were highlighted, which is supported by mention of a wide range of herbs, seeds etc which we know to be spices/condiments not only for food flavouring but also for providing the important phytochemicals beneficial for health promotion and protection. Existence of a concept of a well balanced diet, consisting of all the nutrients and the essential non-nutrients required for cellular function, metabolism and body building, is clearly evident from a scrutiny of the two medical texts. Along with the understanding of the nutritional value of food, the aesthetics and hygiene of how food was to be prepared and served also received much attention. Food properly cooked and served is indeed associated with digestion and assimilation.

Food and drinks with desirable smell, taste and touch is considered to be a source of vital strength for mind, sense organs and body (CS.Sū.27.3). There is elaborate description in the Saṃhitās of how to process and present food preparations, plan and maintain hygiene of the kitchen, and the utensils where food was to be served. Cleanliness of the body and surrounding, which epitomizes the progress of mind, has been considered important for all aspects associated with food consumption. Cleaning of body prior to eating and avoidance of stale food is stressed (CS.Sū.8.20). Purity and cleanliness of drinking water is also mentioned (CS.Sū.27.196-197). The expression of the thought that there can be a variety of food combinations in the presence of abundant eatable substances in plant and animal kingdom 
(CS.Sū.25.36) and different ways of processing and preparing food (CS.Vi.1.21.1-4) speaks highly of the imagination and urge for appetising food as well as avoidance of monotony in dietary practice. It also appears that the knowledge that inclusion of variety in food items afford more benefit to the body than depending on a single item, which is likely to produce deficiency by misbalancing or disturbing equilibrium of dhātus (CS.Śā.6.7-10). Current nutritional guideline does emphasize this point.

It has been categorically mentioned that food has to be properly processed to ensure it is delicious and wholesome (SS.Sū.46.451) and should be cooked faithfully, properly and hygienically in a kitchen which is spacious, clean and well positioned (SS.Sū.46.446-447). Serving of food also necessitated following certain rules and specific recommendations are enumerated (SS.Sū.46.451,454-457). This includes serving of liquid items like juices and meat soup in silver cups and use of stone cups for buttermilk and vegetable soup. Iron cup is to be used for serving ghee and silver cup for liquid gruels. Use of proper food utensils is indeed important for avoiding toxic reactions of food with the material of the container. The seating posture during eating need to be comfortable and food is to be taken in proper time and right measure (SS.Sü.46.465). This code of eating satiates, gets easily digested, promotes strength and maintains equilibrium of dhātus (SS.Sū.46.466-467, 471-474). Drinking pure water in proper quantity is recommended during and after eating (SS.Sü.46.482) as it aids in digestion.

\section{Dietary Recommendation for Diseased Conditions}

Apart from the normal requirement of nourishing food, the healing and preventive role of food items, their harmful effects, beneficial support during treatment of diseases and during convalescence have been asserted throughout the two Samhitās. The dietary planning for the sick and suffering recorded in these texts in context to treatment are well thought of and seems rational. It is interesting to note that all diseases were thought of as vitiation of vāta, pitta and kapha etiologically related to intake of hot food and also eating before previous meal was digested. This expression has been repeated throughout the text implying a pivotal role of food in disease causation. Faulty diet has been emphasized as aggravator of doșas in persons who are delicate, obese and of a sedentary nature (SS.Ci.5.5). Therefore the general advise was to incorporate those food entities that alleviate vāta, pitta and kapha in therapeutics designed for most of the diseases (CS.Sū.25.42-44) and a proper dietary regimen became an important element in management of both external and internal diseases (SS.Ci.5.7). Pathya (wholesome diet) which is not harmful to the body and provide strength is prescribed for the sick during treatment and during recovery (CS.Sū.25.45-50), which is to be planned by the physician on the basis of the measure of diminished dosas (SS.Ci.39.5-6). Mention of food items like śali rice, meat soup, vegetables viz. amalaka and pomegranate and milk find repeated mention in the medical texts in connection with diet for the sick and those recovering after therapy. Milk processed with pañcamūli (root of medicinal herb?), meat soup soured with fruits or soup of cereals are considered wholesome food for those suffering from different disorders of the head, ear, stomach, urinary bladder, blood, joints and ligaments (SS.Ci.4.13).

Fever (jvara) is described as king of all diseases and destructive for all creatures (CS.Ci.3.345). In case of fever arising from different conditions of the vāyu, pitta and kapha, wholesome but light diet of vegetable, lentil or meat soup is recommended along with drinking of plenty of pure water; boiled rice may be given after remission(SS.Utt.39.147-148,253). Boiled milk with sugar, honey and ghee was also thought to be useful in intermittent fever. Solid food is to 
be avoided in acute fever (CS.Ci.3.138) while gruels and bitter substances were considered beneficial (CS.Ci.3.142). Hot or cold water is prescribed according to indication, as appetiser, digestive, anti-pyretic, channel cleanser, for sweating and strength promoting (CS.Ci.3.143144). These recommendations are most suited for remission of fever and relief from most of the discomforts associated with the condition. Saturating drinks of parched paddy, flour or fruit juices with honey and sugar is also suggested (CS.Ci.3.155). Curd water, sugarcane juice or wine may also be taken as per prescription of the physician (CS.Ci.3.156-159). Intake of milk is advised in some type of fevers which are due to predominance of $v a \overline{t a}$ and pitta (CS.Ci.3.167). Recipes for a wide range of food preparation (gruels) of rice and barley mixed with fruit juices, spices and flavouring agents are available for use in different types of fevers (CS.Ci.3,177-193). In general, dietary components which are heavy, hot and unctuous and astringents are to be avoided in acute fever (CS.Ci.3.195-196,330). Many antipyretic extracts of fruits are mentioned among which grape, haritāki, āmalaka etc are highlighted (CS.Ci.3.291). Chronic fevers which cause debility of bodily dhātus are to be managed with a diet which promotes strength and body bulk (CS.Ci.8). Food and diet suggested in fever compares well with currently used dietary protocols which are based on easy digestibility and assimilation.

Various lung disorders including tuberculosis (phthisis) are described (CS.Ci.8.6570,149-172) for which nourishing dietetic regimen are described in great detail (CS.Ci.15.58-72). Well prepared meat along with barley, lentils and fruits were considered excellent for strength and bulk promoting during treatment. Wine followed by meat preparation was also considered beneficial for metabolism and nourishment. In this context it may be pointed out that malnourishment is among one of the predisposing factors of tuberculosis.
Grahani disorders (disorders of the digestive tract) and atisāra (diarrhoea) were believed to arise by overeating of heavy, unctuous, uncooked, cold, sour, alkaline or burning food (CS.Ci.15.112-116). Liquid gruel like vegetable or meat soup mixed with appetisers and post meal drinks like buttermilk and arișta (distilled wine) was the recommendation (SS.Utt.40.25). Fasting has been considered best at the initial state of all types of diarrhoea to be followed by gruels/soups mixed with digestives (SS.Utt.40.158). Mention is made of yavāgu (a type of gruel) which removes thirst, is light, appetising, diuretic and wholesome (CS.Ci.19.71-76,113-116). Red śali rice cooked in goat milk with honey and sugar or meat soup is suggested as diet as well as remedy for atisāra and tender bilva fruit (wood apple) to alleviate abdominal distress (CS.Ci.20,20-25). In all types of vomiting due to gastric irritation, prescription made for patients include meat and vegetable soup with curd and pomegranate (SC.Ci.26,18). For relief from udavarta or formation of wind or flatulence due to different disorders, recommendation was some easily digestible liquid gruels (CS.Ci.22.19-22,25-26).

Trsna or excessive thirst that appears as complication of many diseases is associated with dehydration. This condition was to be managed by providing the patient with plenty of pure, cold drinking water mixed with honey (CS.Ci.22.273) and a dietary preparation of barley, honey and sugar or liquid gruel of sali rice with meat soup(SS.Utt.48,29-30). Meat soup or jiggery water was considered to be pacifiers of thirst (CS.Sū.17.78-82).

Beneficial dietary formulation and possible association of food items with chronic diseases like cancer, diabetes and heart diseases also did not escape attention. Diabetes, the oldest known disease of man, is referred to in Caraka Saṃitā and Suśruta Saṃhitā as a type of prameha or Madhumeha. Excessive eating of heavy, fatty, sour and saline substances, new grains and sweet 
juices in conjunction with lack of exercise and oversleeping were associated with development of madhumeha (CS.Ci.6.18-24) and food recommended in this condition consisted of barley preparation, sali or sastika rice with palatable meat soup, mugda (green gram) or bitter vegetables with oil of ingudi (linseed) and mustard oil (SS.Ci.12.4). Avoidance of sweet diet is prescribed for management diabetic boils (pramehapidika) (SS.Utt.43.3-4). In case of hrdya roga (heart diseases), among other factors, use of hot and rough food in excessive quantity, incompatible and improperly cooked unsuitable food as well as eating during indigestion were to be avoided (SS.Utt.43,14). Diet for these patients is old sali rice with meat soup added with ghee and use of curd and powered sesamum are mentioned (SS.Utt.42.53)

Cancer has found mention in both Caraka Samhitā and Suśruta Samhitā where it is referred to as karkata, arbuda, gulma and granthi with respect to their appearance, nature and site of growth in the body. For patients of gulma or abdominal tumor/lumps lukewarm soup of meat processed with fatty medium and medicinal herbs (trikatu) is a beneficial drink (SS.Utt.42,54) and liquid gruel processed with vāta alleviating drugs is the recommended diet (SS.Utt.42,55). In case of retention of faeces and flatus, milk mixed with fresh ginger is useful (SS.Utt.42.65). Preparation of barley with milk and some fatty substance is also mentioned in this connection (SS.Ni.11. 1718). Māmsarbuda or muscle tumor is specifically mentioned to be due to derangement of doșas as a result of over eating of different forms of meat (SS.Utt.42.75). One suffering from gulma should not eat dried meat, roots, vegetables and fish (SS.Utt.42.100). In case of pain, light warm gruel and soup is suggested (SS.Utt.42.108). Juice of parusaka (Grewia asiatica L.), grape, dates and some aquatic tubers were also considered as remedies for relieving colic pain (CS.Ci.5.183189). Wholesome food and drink and avoidance of etiological factors were considered important for successful management of gulmas (tumors) (CS.Ci.11.27-34). For patients wasted, emaciated or with wounds due to various medical conditions inclusion of items like sugar, barley, wheat, honey and milk along with meat soup was the dietary recommendation (CS.Ci.12.20) and all unwholesome and heavy food were to be avoided (SS. Utt.44.3,18,23,24). Wholesome diet with juice of amalaka, sugar cane and honey are recommended along with mention of iron slag (lauha) for preparation of drug for pānduroga (anemia) caused by aggravated doṣas (CS.Sū.21.4)

Obesity was considered to be due to excessive intake of heavy, sweet and fatty diet, defective metabolism and lack of exercise (CS. $S \bar{u} .21,10-15)$ and over lean persons were small eaters with weak metabolism (CS.Sū.21.51). Both obese and lean persons are considered incapable of all normal activities and mostly prone to or affected with diseases, so the importance of wholesome diet for maintaining body weight was emphasized (SS.Sū.15.34-35). A moderate diet which includes sastika or red śali rice, uail meat, pomegranate and tanduliya are mentioned as food for maintenance of body weight (CS.Sū.21, 2128). Honey, triphala, àmalaka and barley combined with other food items in right proportions suited both groups (SS.Sū.19.16-18). Obesity and overweight is still a growing threat to health at the present time which is associated with high-fat energy dense diets (WHO, 2000).

Surgical patients were to avoid in their diet new cereals, black gram, horse gram, sesamum, green salads and vegetables, sour, salty and pungent food, products of jaggery and flour, dried meat and vegetables, meat, muscle fat, cold water, milk and milk preparations (pāyasa) and wine as they aggravate pathological conditions and have a damaging effect in wound healing (SS.Sū.19.3234). A diet of warm old sali rice with meat of wild animals helps during recovery and healing of wounds; the patients should drink boiled water 
and $\overline{a m a l a k a}$ and dadima are considered beneficial (SS.Ci.1.131). In general dietary prescription for all wound patients is light food in small amount which should be unctuous, warm and appetizing (SS.Ci.3.5,13). During treatment for fracture (bhānga), rough food is to be avoided and cow milk, ghee, meat or pea soup, śâli rice and other health promoting food and drinks are the recommendation (SS.Ci.39.3-5).

For management of complications after unction, emesis, purgation, bloodletting and emanation as measures of treatment for various health disorders, food need to be light and in small measure instead of heavy food, as the digestive power in such conditions are weak (SS.Ci.24.68).

To prevent future ailments, it is necessary to provide nourishing food which will increase strength immediately, sustain body and promote brilliance, energy, memory, ojas and digestive power (SS.Ci.39.6). The diet is to be prescribed on the basis of measure of eliminated dosas which may be regarded as inferior, medium and superior according to the measures (SS.Ni.2.4) It has been advocated that foods which are related to the causes of many ailments need to be avoided. For example where diagnosis of piles (arsas) is discussed, incompatible food and eating before previous food is digested or eating too little is held responsible for causing piles (SS.Ni.2.4), hence these are to be avoided. Predominantly warm liquid diet in small quantities is recommended for piles patients during treatment (SS.Ci.6.4). Items like sali or svastika rice, barley and wheat taken with ghee and milk, soup of nimba (neem) or patola (snake gourd) are mentioned as beneficial in this condition (SS.Ci.6.6). Haritakī (myrobalan) mixed with jaggery taken regularly in the morning is one of the palliative treatments for piles (SS.Ci.6.13); haritakī being digestive and laxative its use in piles is justified.

Faulty diet, eating of unwholesome items and frequent consumption of meat has been associated with various skin diseases (SS.Ni.5.3) (SS. Ci.9.3). Those suffering from skin diseases are to abstain from meat, muscle fat, milk, curd, oil, horse gram, black gram, products of sugarcane, rice flour, sour or incompatible food (SS.Ci.9.4). Bitter group of vegetables and nimbi leaves are recommended for skin disease patients (SS. Ci. 9.5).

Urinary disorders are associated with indulgence in eating of cold, unctuous, sweet, fatty food and drinks (SS.Ni.6,3). Udararoga or abdominal enlargement is associated with poor digestive power increased by unwholesome eating or continuous intake of dry or putrid food (SS.Ni.7.5). Many different conditions are described under Udararoga which include perforation, obstruction, gastritis, constipated condition etc. and dietary sanction are made accordingly. In general heavy food is to be avoided, but in some cases nothing but only milk is recommended as food and drink (SS.Ci.14.4,10). Milk and meat soup of wild animals are prescribed in most of the udararoga (SS.Ci.14,19). Unwholesome and incompatible food is also the cause of internal abscess (SS.Ni.9.15-18).

Many of the observation on association of disease with food items and practices have been identified and clarified by case control studies of recent times, particularly with respect to the chronic (life style) diseases (WHO Study Group, 2003).

These are but only some important examples, from the ancient medical texts under review, of diseased conditions having etiological association with food and a rational dietary approach towards their management to complement therapy. Scanning through the entire volumes of these texts it is inspiring to find how exhaustively nutritional guidelines are provided and all aspects of diet for the patients under treatment and during recuperation have received due attention. 


\section{Dietary Prevention of Diseases}

Both Caraka Samhitā and Suśruta Samhitā show the path for a happy long life which can be lived and enjoyed free from diseases and suffering. In this lifelong path, role of food, diet and nutrition have been projected as a major issue. The perception that intake of regular moderate diet was of utmost importance for remaining disease free is loud and clear all through the Samhitās. It was believed that the essence of food circulating in the body produces dhātus in a balanced state which maintains medium physique, normal activities, strength and tolerance to hunger, thirst, cold, heat, rain and sun(SS.Sü.15.34), implying robust health and immunity. Therefore those who are wise and desire health and happiness should make the best effort to practice the wholesome in respect to diet, conduct and action (CS.Sü.5-8). Consequently the code of conduct defined is directed towards preservation of health as well as prevention of diseases. Food is one of the features of Svasthavrta (observance of the code of conduct for preservation of health) where emphasis is on nourishing food which gives strength, sustains body and promotes life span, brilliance, energy, memory and digestion (SS.Ci.24.68). One taking wholesome food with control over self, lives healthy and for one thousand and sixty nights (CS.Sü.27. 348).

\section{Concluding remarks}

Development and progress in medical science have put forward an integrated approach for management of most diseases. The importance of nutrition, to provide the specific needs of the body for different biological functions was recognized only since the turn of the nineteenth century. It has since been proved beyond doubt that nutritional support and supplementation is to be considered as an essential arm of modern disease management and an additional entity in therapeutic protocols (Webster-Gandy, Madden and Holdsworth 2011). Nutrition, according to
WHO (1971) is the science concerned primarily with the part played by nutrients in body growth, development and maintenance. It is to be noted that a similar or even more enlarged vision on nutrition can be found in the earliest medical texts of India viz. the Caraka Samhitā and Suśruta Sam hitā. The wisdom and insight embodied in these texts in relation to the role of food and nutrition in preservation, protection and promotion of health and disease treatment and prevention is fascinating. A focussed attention to these medical treatises reveal the existence of a highly developed knowledge and understanding in dietetics in early India most of which is applicable to medical and surgical practices even to this day. Almost no aspect of nutrition related to physiological, psychological and pathological conditions had been overlooked in these Samhitās. Responsibility of dietary planning, to provide proper nutrition at all phases of life and in disease management according to the requirement of the patient, was entrusted on the physicians, which in recent times has been shifted to the new specialists - the dieticians, in consultation with the medical professional. In the absence of a clear concept of food and nutrition for the body and mind, neither the definition nor the allotment of duty could have been so precisely depicted. In Caraka Samhitā the grouping of many diseases in the body are based on common symptoms (not necessarily on pathologically as in modern medicine) because their occurrence were attributed to vitiation of three doșas (vāyu, pitta and kapha) which normally exist in harmony. Despite a wide difference in the principles of disease causation in early and modern medical systems, it is not difficult to comprehend and appreciate the ancient perception on food in terms of health and disease in the current context. In fact it is not possible to ignore the existence of a scientific basis to the dietary recommendations made in the CarakaSuśruta Samhitās. Agreed, that it is not possible to fathom the extent of knowledge, if any, on food chemistry from these texts. But the mention of 
specific food items for formulating the "wholesome" dietary combinations do suggest awareness on the biological properties and role of food items in various body functions. For example, the idea of deriving nourishment from a food combination that would provide all the six rasas in the right amount as well as procuring food items from different sources in nature (plant, animal and earth) is indicative of a clear insight of a "Balanced Diet" to include all the essential requisites of nutrition i.e. carbohydrate, protein, fat, vitamins and minerals and in the right proportions. The concept of a balanced diet is well expressed all through the texts with relevant dietary guidelines on food selection. Among innumerable variables inclusion of cereals, pulses, meat, poultry, egg, milk, fruits, vegetables, oils and flavouring agents (spices and herbs) were ensured. Meat was considered as bulk promoting, cereals for providing strength and energy and milk was rated as a complete food. Intake of amalaka, citrus fruits and leafy vegetables were perhaps advised to supplement the macronutrients with the vitamins, minerals and fibre. Fruit juices, wine and other alcoholic drinks were identified as digestive and fatigue alleviating, though plain clean water was ranked as the best of all drinks. Attention is drawn on certain food items like red sali rice among grains, mudga (green gram) and masurika (lentil) among pulses, rohita among fishes, vension among meat, ginger among bulbs, milk among dairy products, honey among sweeteners, seasame oils and ghee (clarified butter) among oils etc. Meat or vegetable soup with ghee and condiments was the tonic of choice in all conditions of health and mention of a wide variety of gruels and mandas (mashed preparations) prepared from cereals, meat, vegetables, ghee and spices in different combinations for patients during treatment and convalescence is bound to find analogy in modern forms of sick diet. The exhaustive list furnished also subscribes to their realization of proper nutrition and diet planning according to the specific needs at different conditions, as well as perhaps availability of the food items in different regions. Prescription of diet made according to body constitution, age, state of health, season, place etc. also seem justified in modern light. An interesting and important point that demands attention is that there seemed to be no taboo or strictures with respect to food (like beef, pork, hen egg, onion, garlic or alcohol) unless they were "unwholesome" for health. However, moderation in intake of alcoholic drinks, minimal consumption of fried and fatty food and avoidance of stale, rotten and unhygenically processed/ prepared food were advocated. Summarising from the two Samhitās it appears a well planned diet, containing a variety of items made palatable by proper cooking in a hygienic atmosphere taken in moderate amount at regular intervals to suit the seasonal needs according to the body constitution, is the basic recommendation for maintenance of health and protection from diseases. The statement that a patient who does not achieve the fruit of diet even if prepared under the guidance of a physician rarely survive (CS.Intr.12.8) definitely is a pointer to the central role assigned to nutrition for existence of life and living. The broad guidelines of Caraka and Suśruta Samhitā have stood the test of time and have its relevance even today. Nutrition is accepted to be a major modifiable determinant of most chronic diseases, and scientific evidence is increasingly supporting the view that diet has both positive and negative influence on health throughout life. Most importantly, dietary adjustments not only determine present health, but also whether an individual will develop or not such diseases like cancer, cardiovascular disease and diabetes in later life. Unfortunately these concepts are yet to be widely practiced in modern medicine (WHO, 2003). Moreover, much remains to be understood with respect to food and nutrition with an objective of defining healthy food that would reduce the occurrence and impact of chronic diseases where food and lifestyle are etiologically associated. Ancient Indian science of healthy living provide 
many guidelines for ensuring a disease free life where role of food and nutrition as well as disciplined eating habits are highlighted. A recently published monograph (Rastogi, 2014) has presented a comprehensive account on the science of dietetics in early Indian medical thought. A more critical analysis and un-prejudiced assessment of ancient Indian medical texts is still underway where the merits and shortcomings of the perception, concept and recommendations on dietetics in early India and their present relevance are likely to be revealed.

Note: All the references are from P.V. Sharma's Caraka Samhitāa. Agniveśa's treatise refined and annotated by Caraka, reducted by Drdhbala, Text with English Translation,Vol.1(2010) and Vol.2(2011), Chaukhamba Orientalia, Varanasi and P.V. Sharma's Suśruta Saṃhitā. English Translation of Text and Dalhana's commentary and critical notes, Vol.1(2010), Vol.2(2010) and Vol.3(2005), Chaukhamba Orientalia, Varanasi.

\section{Acknowledgement}

This article is a part of an ongoing research project supported by the Indian National Science Academy, New Delhi, for which the author is very grateful. The kind academic support received from Prof. (Dr.) Sukla Das is acknowledged with thanks.

\section{Bibliography}

Achaya, KT. A Historical Dictionary of Indian Food, Oxford Univ.Press, 1998

Chattopadhyay, DP. Science and Society in Ancient India, Research India Publ., Calcutta, 1977.

Crayhon R. Nutrition for a longer life, Magna Publ. Mumbai, 1997.

Dash, VB. Fundamentals of Ayurvedic Medicine, Konark Publ.Pvt.Ltd., Delhi, 1978.
Frawley, D. Ayurvedic Healing, Motilal Banarsidas Publ.Pvt.Ltd., Delhi, 1997.

Mennell, S, Murcolt A and Van Otterloo AH. The Sociology of Food : Eating, Diet and Culture, Sage, London, 1993.

Naqvi, NH. A Study of Indian Medicine and Surgery in Gandhara, Motilal Banarsidas Pvt Ltd., Delhi, 2011.

Payne, A and Barker HM (eds). Advancing Dietetics and Clinical Nutrition, Elsevier Churchill Livingstone, London, 2010.

Prakash, Om. Food and Drinks in Ancient India, Munshiram Manoharlal, Delhi, 1961.

Rastogi S (ed.) Ayurvedic Science of Food and Nutrition, Springer, New York, 2014.

Ray, P and Gupta, HN. Caraka Saṃhitā-A Scientific Synopsis, INSA,New Delhi, 1965.

Ray, P., Gupta, HN and Roy, M. Suśruta Saṃhitā -A Scientific Synopsis, New Delhi, 1980.

Saha K. Indian Medical Texts in Central Asia, Firma K.L.Mukhopadhyay, Calcutta, 1985.

Sizer, F.S. and Whitney, E.N. Nutrition : Concepts and Controversies, West Publ.Co, New York, 1994.

Ustin, B and Jacob R. Re-defining Health. Bull. WHO 83(2005): 802.

Webster-Gandy J, Madden A and Holdsworth M (ed.) Oxford Handbook of Nutrition and Dietetics, Oxford Univ.Press, Oxford, 2011.

WHO International Health Conference, New York, June 19-22, 1946.

WHO Technical Report Series No. 477, WHO, Geneva, 1971.

WHO Study Group. Diet, Nutrition and Prevention of Chronic Diseases. Technical Report Series 916, WHO, Geneva, 2003.

WHO, Health for All. Technical Rept. Series. No. 1, 1978.

WHO, Obesity: Preventing and Managing the Global Epidemic. Technical Rept. Series No.894, WHO, Geneva, 2000. 